\title{
TEKNIK AUDIT INVESTIGATIF, PENGALAMAN DAN PROFESIONALISME AUDITOR PADA PENGUNGKAPAN KECURANGAN : KECERDASAN SPIRITUAL SEBAGAI PEMODERASI
}

\author{
Dinda Larasati ${ }^{1}$, Andreas Andreas ${ }^{2}$, Rofika Rofika ${ }^{3 *}$ \\ ${ }^{123}$ Akuntansi, Fakultas Ekonomi dan Bisnis, Universitas Riau, Pekanbaru \\ *E-mail: rofika@lecturer.unri.ac.id
}

\begin{tabular}{l}
\hline Keywords \\
\hline Investigative Audit \\
Techniques, Experience, \\
Professionalism, \\
Spiritual Intelligence, \\
Fraud \\
\hline
\end{tabular}

Article Information

Received:

2020-02-06

Accepted:

2020-02-25

Available online:

2020-03-22

\begin{abstract}
This study aims to determine the effect of investigative audit techniques, auditor experience and auditor professionalism on the disclosure of fraud with spiritual intelligence as a moderating variable. The data used in this study are primary data with a questionnaire as an instrument. The number of samples in this study were 60 respondents. Hypothesis testing in this study was carried out using the statistical test t. Data analysis techniques used in this study are multiple linear regression analysis and moderation regression analysis using the Statistical Product and Service Solution (SPSS) data processing software version 17.0 for windowS. The results of this study indicate that investigative audit techniques have a significant effect on disclosure of fraud. While the auditor's experience and auditor professionalism have no effect on disclosure of fraud. Moderate regression analysis shows that spiritual intelligence can moderate investigative audit techniques, auditor experience and auditor professionalism on disclosure of fraud.
\end{abstract}

\section{PENDAHULUAN}

Fraud atau kecurangan adalah objek utama yang diperangi dalam akuntansi forensik dan audit investigatif. Alasan untuk melakukan kecurangan seringkali dipicu melalui tekanan yang mempengaruhi individu, rasionalisasi, atau kesempatan (opportunity). Kecurangan akan dilakukan jika ada kesempatan dimana seseorang harus memiliki akses terhadap aset atau memiliki wewenang untuk mengatur prosedur pengendalian yang memperkenankan dilakukakannya skema kecurangan. Jabatan, tanggung jawab, maupun otorisasi memberikan peluang untuk terlaksananya kecurangan.

Seseorang yang karena tekanan atau rasionalisasi mungkin akan melakukan kecurangan jika ada kesempatan. Kemungkinan melakukan kecurangan akan semakin kecil jika tidak ada kesempatan. Perangkat yang dapat digunakan untuk memperkecil terjadinya 
kesempatan untuk melakukan kecurangan adalah dengan mengimplementasikan pengendalian internal yang memadai.

Berbagai macam kasus yang terjadi di perusahaan maupun lembaga pemerintahan tidak jarang disebabkan karena faktor kecurangan (fraud). Seiring dengan berkembangnya kompleksitas bisnis dan semakin terbukanya peluang usaha dan investasi menyebabkan risiko terjadinya kecurangan pada perusahaan dan lembaga pemerintahan semakin tinggi. Mengacu ke berbagai kasus baik di dalam maupun di luar negeri menunjukkan bahwa kecurangan dapat terjadi dimana saja (Wahono, 2011). Kasus-kasus kecurangan yang bukan hanya sekedar operasi fiktif belaka yang pernah dilakukan perusahaan ataupun lembaga pemerintahan dalam praktik kecurangan, melainkan juga korupsi yang dikemas dengan apik oleh jajaran manajemen perusahaan yang beberapa waktu ini banyak ditemukan kasus kecurangan yang pada akhirnya terbongkar berkat peran aktif auditor.

Kasus mengenai kecurangan (fraud) sudah banyak terjadi di Indonesia. Menurut hasil survey fraud yang dilakukan oleh Association of Fraud Examiners (ACFE) Indonesia yang bekerjasama dengan Pusat Penelitian dan Pencegahan Kejahatan Kerah Putih (P3K2P), korupsi merupakan kasus fraud yang paling banyak terjadi di Indonesia. Korupsi terjadi dalam 67\% kasus di dalam survey tersebut, diikuti oleh pemindahan aset sebanyak $31 \%$ dan kecurangan laporan keuangan sebanyak 2\%. Jumlah kerugian yang disebabkan oleh korupsi dapat mencapai hingga 10 milyar rupiah sedangkan oleh pemindahan aset mencapai lebih besar lagi dari angka tersebut. Korupsi dianggap sebagai bentuk fraud yang paling merusak dikarenakan jumlah kasusnya yang paling banyak di Indonesia.

Contoh kasus kecurangan lainnya yang terjadi di Indonesia, khususnya Kota Pekanbaru, Provinsi Riau adalah kasus korupsi gorong-gorong yang merugikan negara sebanyak Rp 2,5 Milliar. Tersangka kasus ini adalah direktur pemenang proyek dan 3 tersangka lainnya adalah PNS Dinas Perumahan Kawasan Pemukiman Provinsi Riau yang saat itu menjabat sebagai Pejabat Pelaksana Teknik Kegiatan (PPTK) (news.detik.com).

Upaya menekan dan meminimalkan insiden fraud merupakan aktivitas yang seharusnya dijalankan dengan sungguh-sungguh baik oleh manajemen maupun internal audit pada sektor pemerintahan pusat dan daerah. Badan Pengawasan Keuangan dan Pembangunan (BPKP) merupakan salah satu Aparat Pengawasan Intern Pemerintah (APIP) yang mempunyai tugas pokok dan fungsi melakukan pengawasan sebagaimana diatur dalam Peraturan Presiden Nomor 3 Tahun 2013 tentang Kedudukan, Tugas, Fungsi, Kewenangan, Susunan Organisasi dan Tata Kerja Lembaga Pemerintah Non Kementerian. BPKP selaku lembaga yang memiliki kewenangan untuk melakukan pengawasan keuangan bagi 
pemerintah pusat maupun pemerintah daerah diharapkan dapat meminimalisir dan mengungkapkan berbagai tindakan kecurangan (fraud) yang terjadi.

Dalam rangka melaksanakan tugas di bidang pengawasan tersebut, BPKP melaksanakan kegiatan di bidang keinvestigasian, seperti audit investigatif, audit dalam rangka penghitungan kerugian keuangan negara, audit klaim, audit eskalasi/penyesuaian harga, dan evaluasi hambatan kelancaran pembangunan, serta berbagai kegiatan pencegahan korupsi lainnya. Penugasan audit tersebut diatur lebih lanjut dalam Peraturan Menteri Pendayagunaan Aparatur Negara dan Reformasi Birokrasi Nomor PER/05/M.PAN/03/2008 tentang Standar Audit Aparat Pengawasan Intern Pemerintah (APIP) dan PER/04/M.PAN/03/2008 tentang Kode Etik Aparat Pengawasan Intern Pemerintah (APIP). Kepala BPKP melalui Peraturan Kepala BPKP Nomor: 1314/K/D6/2012 menerbitkan Pedoman Penugasan Bidang Investigasi (PPBI) yang merupakan norma yang menjadi pedoman bagi auditor BPKP dalam merencanakan, melaksanakan, melaporkan, mengendalikan dan memantau tindak lanjut penugasan bidang investigasi, dengan tujuan tercapainya produk bidang investigasi.

Dalam menindaklanjuti berbagai kecurangan (fraud) yang terjadi, maka peran audit investigatif dibutuhkan untuk mendeteksi kecurangan yang terjadi. Deputi Kepala BPKP Bidang Investigasi dalam Acara Monthly Discussion yang dilaksanakan oleh Pengurus ACFE Riau bekerjasama dengan Perwakilan BPKP Provinsi Riau menyampaikan bahwa $80 \%$ kasus korupsi terjadi pada pengadaan barang/jasa dan hampir $80 \%$ korupsi pengadaan barang/jasa tersebut terjadi di pemerintah daerah (provinsi/kabupaten/kota). (www.bpkp.go.id/riau)

Pengungkapan kecurangan dan korupsi dapat dibantu oleh audit investigasi. Audit investigasi merupakan audit khusus yang dilakukan berkaitan dengan adanya indikasi tindak pidana korupsi, penyalahgunaan wewenang serta ketidaklancaran pembangunan. Audit investigasi ini adalah proses mencari, menemukan dan mengumpulan bukti secara sistematis yang bertujuan mengungkapkan terjadi atau tidaknya suatu perbuatan dan pelakunya guna dilakukan tindakan hukum selanjutnya (Pusdiklatwas BPKP, 2010:58). Audit investigatif dalam praktiknya memiliki beberapa jenis teknik. Teknik audit investigatif itu diantaranya teknik audit yang terdiri dari memeriksa fisik dan mengamati, meminta informasi lisan atau tertulis dari auditee dan konfirmasi, memeriksa dokumen, review analitikal dan menghitung kemballi, teknik perpajakan, follow the money, computer forensic, net worth method dan teknik kunci. Teknik-teknik tersebut akan digunakan selama proses investigasi dimulai dari pendeteksian kecurangan hingga perhitungan jumlah kerugian yang dialami negara (Rosalia, 2015). 
Hasil penelitian Sundari (2018), Rahmayani (2014) dan Hasbi (2019) menyatakan bahwa melalui teknik-teknik audit investigatif, auditor dapat mengungkapan kecurangan. Sedangkan penelitian yang dilakukan oleh Rozali dan Darliana (2015) menyatakan bahwa secara teori dan praktik tidak ada teknik audit investigatif yang dipilih sebagai teknik paling efektif mengungkapkan kasus money laundering berdasarkan perspektif akuntan forensik.

Dalam rangka menindaklanjuti berbagai kecurangan (fraud) yang terjadi, maka peran audit investigatif dibutuhkan untuk mendeteksi kecurangan yang terjadi dan dalam hal mendeteksi kecurangan, kecerdasan spiritual dapat mendukung auditor dalam melakukan audit investigatif. Kecerdasan spiritual yang dimiliki seorang auditor dalam proses investigatif dapat memutuskan mana yang baik dan tidak baik, sehingga dalam pelaksanaan investigatif auditor dapat menentukan kebenaran permasalahan melalui proses pengujian, pengumpulan dan pengevaluasian bukti-bukti yang relevan dengan perbuatan kecurangan dan juga dapat mengungkapkan fakta-fakta kecurangan sehingga dapat mengidentifikasi pelaku kecurangan.

Seorang Auditor juga harus memiliki pengalaman yang ditunjukkan dengan jumlah penugasan praktik audit yang pernah dilakukan oleh auditor. Pengalaman yang dimiliki oleh auditor akan membantu auditor dalam meningkatkan pengetahuannya mengenai kekeliruan dan kecurangan (Surtiyana, 2014). Pengalaman auditor diyakini dapat mempengaruhi seorang auditor dalam melaksanakan prosedur audit yang efektif untuk membuktikan adanya kecurangan. Menurut Novianti dan Bandi (2011) pengalaman yang dimaksud adalah pengalaman auditor dalam melakukan pemeriksaan laporan keuangan dan penugasan audit di lapangan baik dari segi lamanya waktu, maupun banyaknya penugasan audit yang pernah dilakukan.

Pengalaman seorang auditor menjadi salah satu faktor yang mempengaruhi auditor karena auditor yang berpengalaman dapat mendeteksi adanya kecurangan pada laporan keuangan. Pengalaman audit dapat ditunjukan dengan jumlah pelaksanaan prosedur audit yang pernah dilakukan oleh auditor tersebut. Membuktikan kecurangan merupakan suatu tantangan bagi auditor, hal ini bisa disebabkan karena auditor belum memiliki banyak pengalaman dalam membuktikan kecurangan atau kecurangan yang telah disamarkan oleh pihak lain yang sebelumnya telah mengantisipasi bagaimana auditor berpikir dan bertindak (Yuhertiana, 2005). Hasil penelitian Novianti dan Bandi (2011) menyatakan bahwa auditor yang berpengalaman akan memiliki pengetahuan dan kekeliruan dan kecurangan yang lebih banyak sehingga akan menghasilkan kinerja yang lebih baik dalam mendeteksi keasus-kasus kecurangan dibandingkan dengan auditor yang tidak berpengalaman. Sedangkan penelitian 
yang dilakukan oleh Asad (2016) menyatkaan bahwa pengalaman auditor tidak mempengaruhi pengungkapan fraud.

Seorang auditor diwajibkan memiliki profesionalisme sehingga dapat mengungkapkan kecurangan sesuai standar yang berlaku (Nurmin, 2017). Seorang auditor dikatakan profesional apabila memenuhi tiga syarat, yaitu berkeahlian, berpengetahuan dan berkarakter. Dharmawan (2013), dalam penelitiannya menjelaskan salah satu faktor yang mempengaruhi profesionalisme auditor adalah kecerdasan spiritual. Seseorang yang mempunyai kecerdasan spiritual tinggi akan lebih etis (sesuai dengan norma dan aturan) karena mempunyai rasa moral dan dapat menyesuaikan diri dengan aturan sesuai dengan apa kata hatinya. Profesionalisme seorang auditor akan menjadi semakin penting apabila profesionalisme tersebut dihubungkan dengan hasil kerja individunya yang akan menunjukkan tingkat profesionalisme terhadap hasil kerja tersebut agar auditor dapat mempertimbangkan cara terbaik mendapatkan bukti dan memberikan saran untuk pencegahan fraud (Sastiana, 2016).

Ketidak konsistenan hasil penelitian diatas menyebabkan peneliti ingin meneliti kembali penyebab pengungkapan kecurangan. Penelitian ini berpedoman pada penelitian sebelumnya yang dilakukan oleh Nurmin (2017) dan Setiawati dan Sari (2016) mengenai Pengaruh Profesionalisme Auditor Terhadap Pengungkapan Kecurangan. Perbedaan penelitiannya, pertama, peneliti menambah variabel independen yaitu teknik audit investigatif, pengalaman auditor dan kecerdasan spritual sebagai variabel moderasi dengan teori pendukung yang berbeda. Kedua, penelitian dilakukan di Kantor Perwakilan Badan Pengawasan Keuangan dan Pembangunan (BPKP) Provinsi Riau sedangkan penelitian sebelumnya dilakukan di kantor Badan Pemeriksa Keuangan Republik Indonesia (BPK RI) Perwakilan Provinsi Sulawesi Tenggara. Ketiga, penelitian ini menggunakan variabel moderasi kecerdasan spiritual. Hal ini didasarkan pada Dharmawan (2013) yang mengungkapkan seseorang yang mempunyai kecerdasan spiritual tinggi maka akan meiliki perilaku sesuai dengan norma sehingga dapat mempengaruhi perilakunya apakah akan mengungkpkan kecurangan atau tidak.

Berdasarkan latar belakang masalah yang telah dipaparkan di atas, maka penelitian ini bertujuan untuk menganalisis teknik auudit investigatif, pengalaman auditor dan profesionalisme auditor terhadap pengungkapan kecurangan dengan kecerdasan spritual sebagai variabel moderasi. 


\section{PENGEMBANGAN HIPOTESIS}

\section{Pengaruh Teknik Audit Investigatif terhadap Pengungkapan Kecurangan}

Dalam pengungkapan kecurangan ( $f r a u d)$, seorang auditor harus memiliki kemampuan untuk membuktikan adanya kecurangan yang memungkinkan terjadi dan sebelumnya telah terdeteksi oleh berbagai pihak. Untuk itu kemampuan investigasi sangat penting bagi auditor dalam menjalankan tugasnya. Seorang auditor melakukan suatu investigasi apabila ada dasar yang layak sehingga auditor dapat mereka-reka mengenai apa, bagaimana, siapa, dan pertanyaan lain yang diduganya relevan dengan pengungkapan kasus kecurangan (Fauzan et al, 2015).

Dalam pengungkapan kasus kecurangan, auditor melakukan investigasi kasus dengan melakukan pemeriksaan yang lebih rinci dan menemukan fakta-fakta terkait kasus tersebut. Investigasi yang dilakukan dalam pengungkapan kecurangan telah dimodifikasi dengan beberapa teknik tambahan yang cukup sering digunakan oleh para auditor investigatif.

Kecurangan saat ini sangat banyak terjadi. Penyelesaian terhadap kasus-kasus tidak mungkin dilakukan dengan cepat dan terburu-buru melainkan dengan prosedur yang tepat agar bukti yang kuat dapat diperoleh. Kecurangan sangat sulit diketahui tanpa terutama kecurangan dalam bentuk manipulasi pelaporan.

Audit investigatif adalah salah satu cara yang efektif untuk mengungkapkan adanya kecurangan dalam bentuk apapun karena audit investigatif dilakukan oleh seorang ahli akuntansi dan auditing sehingga dapat mengungkapkan kecurangan. Audit investigatif dilaksanakan dengan menggunakan teknik audit yang sama dengan teknik audit pada audit laporan keuangan dan beberapa teknik lainnya, dengan dilakukannya audit investigatif penyidik dapat memperoleh kepastian apakah tersangka benar-benar bersalah atau tidak karena tugas auditor dalam audit investigatif adalah memperoleh bukti, terutama bukti surat yang sangat dibutuhkan oleh penyidik untuk memperkuat apapun dugaan, tetapi pelaksanaan audit investigatif haruslah seefektif mungkin.

Penelitian sebelumnya dilakukan oleh Tries et al (2018) menyatakan bahwa teknik audit investigatif berpengaruh signifikan terhadap pendeteksian kecurangan.Rozali dan Darliana (2015) menyampaikan bahwa teknik audit investigatif paling efektif dalam pengungkapan money laundering berdasarkan perspektif akuntan forensik. Fauzan et al (2015) menyatakan bahwa audit investigatif berpengaruh sangat baik terhadap pengungkapan fraud. Berdasarkan uraian tersebut, maka dapat dirumuskan hipotesis:

$\mathrm{H}_{1}$ : Teknik audit investigatif berpengaruh terhadap pengungkapan kecurangan. 


\section{Pengaruh Pengalaman Auditor terhadap Pengungkapan Kecurangan}

Faktor keahlian lain yang berpengaruh dalam mendeteksi dan mencegah kecurangan adalah pengalaman. Pengalaman kerja telah dipandang sebagai suatu faktor penting dalam memprediksi kinerja auditor, sehingga pengalaman dimasukkan sebagai salah satu persyaratan dalam memperoleh izin menjadi akuntan di Indonesia berdasarkan SK Menkeu No. 17/PMK.01/2008.

Kematangan auditor dalam melakukan audit tidak hanya ditentukan oleh pengetahuan yang diperoleh selama pendidikan namun juga tidak kalah pentingnya adalah pengalaman yang diperoleh selama melakukan pemeriksaan. Tentu tidak mengherankan apabila cara pandang dan menanggapi informasi yang diperoleh selama melakukan pemeriksaan antara auditor yang berpengalaman dan auditor yang kurang berpengalaman berbeda. Auditor yang sudah memiliki pengalaman audit diyakini mampu mendeteksi kecurangan karena pengalamannya dalam menghadapi berbagai kasus peristiwa yang wajar maupun tidak wajar, semakin banyak pengalaman yang dimiliki auditor semakin besar kemampuan auditor dalam mengatasi dan menganalisis suatu masalah serta semakin meningkat efektivitas pelaksanaan prosedur audit dalam pembuktian kecurangan.

Penelitian sebelumnya yang dilakukan oleh Mulyati (2015) terhadap seluruh auditor investigatif di Badan Pegawasan Keuangan dan Pengawasan (BPKP) perwakilan Jawa Barat. Pengalaman auditor memiliki pengaruh namun tidak berpengaruh secara signifikan terhadap efektivitas pelaksanaan prosedur audit dalam pembuktian kecurangan. Hasilnya memberi indikasi bahwa semakin banyak pengalaman auditor atau jumlah jam terbang seorang auditor maka dapat membantu auditor dalam meningkatkan pengetahuannya terhadap efektivitas pelaksanaan prosedur audit dalam pembuktian kecurangan. Pernyataan diperkuat dengan penelitian Novianti dan Bandi (2011) menyebutkan bahwa auditor yang berpengalaman akan memiliki pengetahuan tentang kekeliruan dan kecurangan yang lebih banyak sehingga akan menghasilkan kinerja yang lebih baik dalam mendeteksi kasus-kasus kecurangan dibandingkan dengan auditor yang tidak berpengalaman. Berdasarkan uraian tersebut, maka dapat dirumuskan hipotesis:

\section{$\mathrm{H}_{2}$ : Pengalaman Auditor Investigatif berpengaruh terhadap pengungkapan kecurangan.}

\section{Pengaruh Profesionalisme Auditor terhadap Pengungkapan Kecurangan}

Program audit investigatif harus diarahkan untuk mengumpulkan bukti-bukti yang cukup dan kompeten sehingga kasus kecurangan yang sedang ditangani dapat terungkap. Oleh sebab itu, dalam pelaksanaannya amat dibutuhkan auditor-auditor yang profesionalisme dan 
memiliki karakteristik khusus. Seseorang auditor dikatakan profesionalisme jika memenuhi tiga kriteria, yaitu mempunyai keahlian untuk melaksanakan tugas sesuai dengan bidangnya, melaksanakan suatu tugas atau profesii dengan menetapkan standar baku di bidang profesi yang bersangkutan dan menjalankan tugas profesinya dengan memenuhi etika profesi yang telah ditetapkan.

Dalam penelitian Ramadhaniyati dan Haryati (2014) menjelaskan bahwa profesionalisme auditor internal berpengaruh signifikan dalam mencegah kecurangan (fraud) dengan koefisien negatif. Artinya, semakin auditor internal itu profesional semakin tidak bisa mencegah kecurangan (fraud). Hasil ini menunjukkan bahwa profesionalisme auditor internal masih diragukan, karena belum tentu auditor internal yang profesional bisa mencegah kecurangan ( fraud), bisa jadi auditor internal yang profesional melakukan tindak kecurangan (fraud) atau memanfaatkan situasi yang ada.

Hasil berbeda ditunjukkan oleh penelitian Widyaastuti dan Padmudji (2009) profesionalisme mempunyai pengaruh signifikan yang positif terhadap kemampuan auditor dalam mendeteksi dan mencegah kecurangan (fraud). Dalam upaya mengungkapan fraud membutuhkan kinerja dan tindakan profesional dari auditor karena tidak mungkin fraud bisa dicegah dan dideteksi jika auditor tidak menjalankan peranan dan tanggung jawabnya secara profesional sehingga masyarakat yang menjadi klien bisa puas terhadap kinerja seorang auditor. Jika seorang auditor bersikao profesional itu bisa meminimalisir terhadap tindak kecurangan (fraud). Berdasarkan penjelasan tersebut maka dapat dirumuskan hipotesis :

\section{$\mathrm{H}_{3}$ : Profesionalisme Auditor berpengaruh terhadap pengungkapan kecurangan.}

\section{Kecerdasan Spritual Memoderasi Teknik Audit Investigatif, Pengalaman Auditor dan}

\section{Profesionalisme Auditor terhadap Pengungkapan Kecurangan}

Kecerdasan spiritual adalah kecerdasan untuk mendapatkan solusi ketika menghadapi dan memecahkan masalah dalam kehidupannya, dan mampu memaknai semua hal yang dilakukan sehingga dapat mengaktualisasikan diri. Dalam konteks Auditor, spiritualitas memiliki makna bahwa seorang auditor memiliki kehidupan personal yang berkembang dan dikembangkan dengan melakukan pekerjaan yang relevan, berarti, dan menantang (Erisna, 2012). Hal ini berarti merupakan konfigurasi yang saling berhubungan antara ide-ide, peristiwa dan orang-orang. Kecerdasan spriritual merupakan setiap yang ada pada diri sendiri harus diterapkan komitmen, moral, kejujuran, transparan dan kebijaksanaan dalam bekerja agar dapat menjalankan tugasnya dengan baik.

Kecerdasan spiritual memungkinkan seseorang untuk menyatukan hal-hal yang 
bersifat intra personal dan interpersonal, serta menjembatani kesenjangan antara diri dan orang lain (Zohar dan Marshall, 2007). Salah satu wujud dari kecerdasan spiritual ini adalah sikap moral yang dipandang luhur oleh pelaku.

Pengungkapan fraud dapat dibantu oleh auditor yang akan melakukan suatu penyidikan. Audit investigatif adalah serangkaian hubungan dalam pemeriksaan fraud (Sayyid, 2014). Salah satu cara penting untuk mengidentifikasi dan menemukan kecurangan adalah melakukan audit investigatif. Dalam pelaksanaan audit investigatif, maka auditor investigatif harus memahami dan mengetahui teknik audit yang digunakan dan kemampuan untuk membuktikan adanya kecurangan yang kemungkinanan dapat terjadi yang tidak terdeteksi oleh berbagai pihak. Auditor yang sudah berpengalaman dalam menanggapi kecurangan akan lebih mudah mendeteksi kecurangan dan mengungkapkan kecurangan dikarenakan auditor tersebut sudah mengetahui titik-titik peluang untuk melakukan kecurangan.

Auditor yang sudah berpengalamanpun adakalanya mengalami kesulitan dalam mengungkapkan kecurangan. Hal ini biasanya terjadi pada auditor yang jarang menemuan terjadinya kecurangan di laporan keuangan. Dengan adanya kecerdasan spiritual akan mendukung dan membantu pengalaman auditor untuk mengungkapkan kecurangan.

Profesionalisme kerja seorang auditor sangatlah penting dilakukan atau dilaksanakan karena dapat memberikan kontribusi dan pelayanan yang optimal kepada pemakai jasa auditor untuk pengambilan keputusan. Sikap profesional inilah yang sangat diperlukan, dimana auditor mempunyai kewajiban untuk mematuhi prinsip-prinsip fundamental etika akuntan atau kode etik akuntan yang telah ditetapkan. Dalam melakukan profesionalisme kerja, seorang auditor haruslah memiliki kecerdasan spritual dalam melakukan tugasnya.

Tanpa adanya kecerdasan spiritual sangat sulit untuk auditor menyelesaikan konflik yang menjadi bagian atau resiko profesi dan memikul tanggung jawab seperti apa yang disebutkan dalam pedoman kode etik akuntan Indonesia serta tidak menyalahgunakan kemampuan dan keahlian merupakan amanah yang dimilikinya kepada jalan yang tidak dibenarkan. Hasil tersebut dapat berpengaruh terhadap hasil kinerja mereka (Lisda, 2009).

Kemampuan bersikap fleksibel yang dimiliki oleh auditor yaitu mampu menyesuaikan diri secara spontan dan aktif untuk mencapai hasil yang baik, memiliki pandangan yang pragmatis (sesuai kegunaan), dan efisien tentang realitas. Kesadaran diri yang tinggi seorang auditor yaitu adanya kesadaran yang tinggi dan mendalam sehingga bisa menyadari berbagai situasi yang datang dan menanggapinya.

Dalam penelitian Dharmawan (2013) menjelaskan faktor yang mempengaruhi 
profesionalisme auditor yaitu salah satunya kecerdasan spiritual, seseorang yang mempunyai kecerdasan spiritual tinggi akan lebih etis (sesuai dengan norma dan aturan) karena mempunyai rasa moral dan dapat menyesuaikan diri dengan aturan sesuai dengan apa kata hatinya.

Hasil penelitian yang dilakukan Hasbi (2019) menemukan kecerdasan spiritual memoderasi pengaruh audit investigatif dan profesionalisme terhadap pengungkapan kecurangan. Berdasarkan penelitian tersebut maka dapat dirumuskan hipotesis :

\section{H4: Kecerdasan spritual memoderasi pengaruh teknik audit investigatif terhadap pengungkapan kecurangan.}
H5: Kecerdasan spritual memoderasi pengaruh pengalaman Auditor investigatif terhadap pengungkapan kecurangan
H6: Kecerdasan spritual memoderasi pengaruh profesional Auditor terhadap pengungkapan kecurangan

\section{METODE PENELITIAN}

\section{Lokasi Penelitian}

Penelitian ini dilakukan di wilayah Pekanbaru bertempat pada kantor Badan Pengawasan Keuangan dan Pembangunan (BPKP) Perwakilan Provinsi Riau. Waktu yang digunakan dalam penelitian ini dari tahun 2019 sampai selesai.

\section{Populasi dan Sampel}

Populasi dalam penelitian ini adalah seluruh auditor yang bekerja pada Kantor Perwakilan BPKP Provinsi Riau. Berdasarkan data PPID (2019), auditor yang bekerja pada Perwakilan BPKP Provinsi Riau khusus audit investigatif berjumlah 60 orang.

Sedangkan sampel dalam penelitian ini menggunakan metode Sampel jenuh yaitu seluruh populasi dijadikan sebagai sampel. Sampel dalam penelitian ini adalah 60 auditor yang bekerja di Perwakilan BPKP Provinsi Riau.

\section{Jenis Sumber Data}

Data yang digunakan dalam penelitian ini adalah data primer. Data yang digunakan dalam penelitian ini adalah berupa data primer yaitu data yang diperoleh secara langsung dari sumber penelitian yakni dari sumber asli (tidak melalui perantara) yang secara khusus dikumpulkan oleh peneliti untuk menjawab pertanyaan penelitian (Indriantoro, 200; 147). Data primer dalam penelitian ini diperoleh dengan cara menyebarkan kuisioner langsung kepada para aparatur/auditor yang terlibat langsung dalam pemeriksaan pada Kantor 
Perwakilan BPKP Provinsi Riau.

\section{Teknik Pengumpulan Data}

Metode pengumpulan data dalam penelitian ini menggunakan kuisioner yang pertanyaan-pertanyaan dibagi menjadi beberapa bagian dan merupakan gabungan dari beberapa dari beberapa dari penelitian terdahulu.

\section{Definisi Operasional dan Pengukuran Variabel}

Berikut adalah operasionalisasi variabel yang diukur dengan menggunakan skala ordinal 5 poin, mulai dari poin 1 sangat tidak setuju sampai dengan 5 sangat setuju

Tabel 1

Instrumen Penelitian

\begin{tabular}{|c|c|c|c|}
\hline No. & Variabel & Indikator & Skala \\
\hline 1. & $\begin{array}{ll}\text { Teknik } & \text { Audit } \\
\text { Investigatif } & \end{array}$ & $\begin{array}{l}\text { a. Ilmu audit investigatif } \\
\text { b. Teknik audit investigatif dan cara memperoleh bukti }\end{array}$ & Ordinal \\
\hline 2. & $\begin{array}{l}\text { Pengalaman } \\
\text { Auditor }\end{array}$ & $\begin{array}{l}\text { a. Mampu membuat keputusan } \\
\text { b. Dapat mengembangkan karir } \\
\text { c. Mampu melakukan tugas } \\
\text { d. Mampu mengatasi permasalahan } \\
\text { e. Mampu menganalisis masalah } \\
\text { f. Mampu mendeteksi dan mengungkapkan kecurangan } \\
\text { g. Lama kerja sebagai auditor } \\
\text { h. Peningkatan kompetensi sebagai auditor }\end{array}$ & Ordinal \\
\hline 3. & $\begin{array}{l}\text { Profesionalisme } \\
\text { Auditor }\end{array}$ & $\begin{array}{l}\text { a. Kemampuan dalam proses pengauditan } \\
\text { b. Profesional terhadap pekerjaan } \\
\text { c. Kemampuan auditor dalam berpikir kritis } \\
\text { d. Transparansi } \\
\text { e. Patuh pada peraturan }\end{array}$ & Ordinal \\
\hline 4. & $\begin{array}{l}\text { Kecerdasan } \\
\text { Spiritual }\end{array}$ & $\begin{array}{l}\text { a. Mudah beradaptasi dengan lingkungan yang baru } \\
\text { b. Dapat menerima pendapat orang lain } \\
\text { c. Menghadapi semua situasi dengan baik } \\
\text { d. Imam kepada tuhan yang maha esa } \\
\text { e. Memanfaatkan waktu dengan baik } \\
\text { f. Mempunyai prinsip } \\
\text { g. Dapat menolong sesama } \\
\text { h. Mampu berimajinasi }\end{array}$ & Ordinal \\
\hline 5. & $\begin{array}{l}\text { Pengungkapan } \\
\text { Fraud }\end{array}$ & $\begin{array}{ll}\text { a. } & \text { Prosedur audit } \\
\text { b. } & \text { Teknik audit investigatif } \\
\text { c. } & \text { Memahami karakteristik kecurangan } \\
\text { d. } & \text { Efek bagi pelaku kecurangan } \\
\text { e. } & \text { Laporan hasil audit investigatif } \\
\text { f. } & \text { Melaksanakan pemantauan } \\
\text { g. } & \text { Metode pengungkapan kecurangan }\end{array}$ & \\
\hline
\end{tabular}

\section{Metode Analisis Data}

Penelitian ini mempunyai enam hipotesis yang diuji dengan menggunakan bantuan software SPSS (Statistical Product and Service Solution). Untuk menguji hipotesis 1, hipotesis 2, hipotesis 3 digunakan model analisis regresi berganda sebagai berikut: 
Model 1 :

$$
\mathbf{Y}=\mathbf{a}+\boldsymbol{\beta}_{1} \mathbf{X}_{1}+\boldsymbol{\beta}_{2} \mathbf{X}_{2}+\boldsymbol{\beta}_{3} \mathbf{X}_{3}+\mathbf{e}
$$

Untuk menguji hipotesis 4, hipotesis 5 dan hipotesis 6 digunakan model analisis regresi moderasi dalam penelitian ini dapat dirumuskan sebagai berikut :

Model 2:

$$
\begin{aligned}
& \mathbf{Y}=\mathbf{a}+\boldsymbol{\beta}_{1} \mathbf{X}_{\mathbf{1}}+\boldsymbol{\beta}_{2} \mathbf{Z}+\boldsymbol{\beta}_{\mathbf{3}} \mathbf{X}_{\mathbf{1}} \mathbf{Z}+\mathbf{e} \\
& \mathbf{Y}=\mathbf{a}+\boldsymbol{\beta}_{1} \mathbf{X}_{\mathbf{2}}+\boldsymbol{\beta}_{2} \mathbf{Z}+\boldsymbol{\beta}_{\mathbf{3}} \mathbf{X}_{\mathbf{2}} \mathbf{Z}+\mathbf{e} \\
& \mathbf{Y}=\mathbf{a}+\boldsymbol{\beta}_{1} \mathbf{X}_{\mathbf{3}}+\boldsymbol{\beta}_{2} \mathbf{Z}+\boldsymbol{\beta}_{\mathbf{3}} \mathbf{X}_{\mathbf{3}} \mathbf{Z}+\mathbf{e}
\end{aligned}
$$

Dimana:

$$
\begin{array}{ll}
\mathrm{Y} & =\text { Pengungkapan Fraud } \\
\mathrm{a} & =\text { Konstanta } \\
\mathrm{b} & =\text { Koefisien Regresi } \\
\mathrm{X}_{1} & =\text { Teknik Audit Investigatif } \\
\mathrm{X}_{3} & =\text { Pengalaman Auditor Investigatif } \\
\mathrm{X}_{2} & =\text { Profesionalisme Auditor } \\
\mathrm{Z} & =\text { Kecerdasan Spritual } \\
\mathrm{e} & =\text { Erorr }
\end{array}
$$

\begin{tabular}{|c|c|c|c|c|c|}
\hline & $\mathrm{N}$ & Min & Max & Mean & Std. Deviation \\
\hline Teknik Audit Investigatif (X1) & 56 & 36.00 & 45.00 & 40.79 & 3.290 \\
\hline Pengalaman Auditor (X2) & 56 & 17.00 & 40.00 & 33.98 & 4.559 \\
\hline Profesionalisme Auditor (X3) & 56 & 32.00 & 55.00 & 47.11 & 4.920 \\
\hline Kecerdasan Spritual (Z) & 56 & 40.00 & 65.00 & 54.05 & 6.004 \\
\hline Pengungkapan Fraud (Y) & 56 & 32.00 & 50.00 & 42.43 & 3.977 \\
\hline Valid N (listwise) & 56 & & & & \\
\hline
\end{tabular}

\section{HASIL PENELITIAN DAN PEMBAHASAN}

\section{Hasil Uji Statistik Deskriptif}

Tabel berikut menunjukkan hasil statistik deskriptif berdasarkan data yang diperoleh dari responden.

\section{Tabel 2}

Hasil Uji Deskriptif Statistik

Sumber: Data Olahan, 2019

Dari tabel di atas dapat dilihat statistik penelitian yakni Teknik Audit Investigatif (X1) dengan nilai minimun 36, nilai maksimum sebesar 45. Nilai tengah atau mean adalah 40.79 dengan standar deviasi 3.290. Pengalaman Auditor (X2) dengan nilai minimun 17, nilai maksimum sebesar 40. Nilai tengah atau mean adalah 33.98 dengan standar deviasi 4.559. Profesionalisme Auditor (X3) dengan nilai minimun 32, nilai maksimum sebesar 55. Nilai tengah atau mean adalah 47.11 dengan standar deviasi 4.920. Kecerdasan Spiritual (moderasi) 
dengan nilai minimun 40 , nilai maksimum sebesar 65 . Nilai tengah atau mean adalah 54.05 dengan standar deviasi 6.004. Pengungkapan Kecurangan (Y) dengan nilai minimun 32, nilai maksimum sebesar 50. Nilai tengah atau mean adalah 42.43 dengan standar deviasi 3.977.

\section{Hasil Uji Analisi Regresi Berganda}

Hasil analisis regresi berganda dengan menggunakan program SPSS untuk pengujian hipotesis 1, hipotesis 2 dan hipotesis 3 disajikan pada tabel 3 berikut.

\section{Tabel 3}

\section{Hasil Uji Analisis Regresi Berganda H1, H2, dan H3}

\begin{tabular}{|c|c|c|c|c|c|c|}
\hline \multicolumn{7}{|c|}{ Coefficients $^{\mathrm{a}}$} \\
\hline \multirow[b]{2}{*}{ Model } & & \multicolumn{2}{|c|}{ Unstandardized Coefficients } & $\begin{array}{l}\text { Standardized } \\
\text { Coefficients }\end{array}$ & \multirow[b]{2}{*}{$\mathrm{t}$} & \multirow[b]{2}{*}{ Sig. } \\
\hline & & B & Std. Error & Beta & & \\
\hline \multirow[t]{4}{*}{1} & (Constant) & 33.188 & 5.149 & & 6.445 & .000 \\
\hline & Teknik Audit Investigatif & .309 & .134 & .282 & 2.308 & .024 \\
\hline & Pengalaman Auditor & -.177 & .129 & -.591 & -1.374 & .174 \\
\hline & Profesionalisme Auditor & .078 & .079 & .430 & .996 & .323 \\
\hline
\end{tabular}

Berdasarkan hasil analisis regresi berganda di atas dapat disimpulkan bahwa variabel teknik audit investigasi berpengaruh terhadap pengungkapan fraud. Sedangkan variabel pengalaman auditor dan professional auditor tidak berpengaruh terhadap pengungkapan fraud. Sedangkan variabel pengalaman auditor dan profesionalisme auditor tidak berpengaruh terhadap pengungkapan fraud. Pembahasan untuk masing-masing hipotesis adalah sebagai berikut:

\section{Pengaruh Teknik Audit Investigatif Terhadap Pengungkapan Kecurangan}

Berdasarkan Tabel 2, pengaruh teknik audit investigatif (X1) terhadap pengungkapan fraud memiliki t hitung sebesar 2.308. Oleh karena $\mathrm{t}$ hitung $>\mathrm{t}$ tabel $(2,308>2,007)$, maka dapat disimpulkan bahwa H1, diterima, artinya secara parsial ada pengaruh signifikan antara teknik audit investigatif terhadap pengungkapan fraud. Jika dilihat dari signifikan variabel teknik audit investigatif (X1) memiliki nilai signifikan sebesar 0,024 (kecil dari $\alpha=5 \%$ ). Artinya teknik audit investigatif berpengaruh signifikan terhadap pengungkapan fraud.

Audit investigatif dilaksanakan dengan menggunakan teknik audit yang sama dengan teknik audit pada audit laporan keuangan dan beberapa teknik lainnya. Dengan dilakukannya audit investigatif penyidik dapat memperoleh kepastian apakah tersangka benar-benar bersalah atau tidak karena tugas auditor dalam audit investigatif adalah memperoleh bukti, terutama bukti surat yang sangat dibutuhkan oleh penyidik untuk memperkuat apapun dugaan, tetapi pelaksanaan audit investigatif haruslah seefektif mungkin. Hasil penelitian ini sejalan 
dengan penelitian sebelumnya dilakukan oleh Tries et al (2018), Hasbi (2019) menemukan bahwa teknik audit investigatif berpengaruh signifikan terhadap mendeteksi kecurangan. .

\section{Pengaruh Pengalaman Auditor Terhadap Pengungkapan Kecurangan}

Dari hasil pengolahan data di Tabel 2 dapat dilihat pengaruh pengalaman auditor terhadap pengungkapan fraud memiliki t hitung sebesar -1.374 . Oleh karena $-\mathrm{t}$ hitung $>-\mathrm{t}$ tabel (-1.374> -2,007), maka dapat disimpulkan bahwa H2 ditolak. Artinya tidak ada pengaruh pengalaman auditor terhadap pengungkapan kecurangan. Jika dilihat dari signifikan variable pengalaman auditor $\left(\mathrm{X}_{2}\right)$ memiliki nilai signifikan sebesar 0,174 (besar dari $\alpha=5 \%$ ). Artinya tidak ada pengaruh signifikan pengalaman auditor terhadap pengungkapan kecurangan.

Pengalaman auditor tidak berpengaruh terhadap pengungkapan kecurangan karena auditor yang sudah memiliki pengalaman lebih dari satu tahun dan sudah banyak melakukan penugasan bisa juga mengalami kegagalan dalam melakukan pengungkapan kecurangan.

Kegagalan tersebut bisa disebabkan karena kesulitan dalam memperoleh data dan informasi yang dibutuhkan, tidak mengambil pertimbangan dalam membuat keputusan, kegagalan dalam mencari penyebab munculnya kesalahan, tidak profesional dalam memprediksi dan mendeteksi masalah, kurang teliti dan kurang cermat dalam melakukan pemeriksaan dan kurangnya belajar dari kegagalan dan keberhasilan yang pernah dialami.

Penelitian ini tidak berhasil mendukung hasil penelitian Bandi (2011) yang menemukan pengalaman auditor berpengaruh terhadap pengungkapan kecurangan. Penelitian ini sejalan dengan Siti Rahayu (2018) dan Millasari (2018) yang hasil penelitiannya menyatakan bahwa pengalaman auditor tidak berpengaruh terhadap pengungkapan kecurangan.

\section{Pengaruh Profesionalisme Auditor Terhadap Pengungkapan Kecurangan}

Berdasarkan Tabel 3 bahwa pengaruh profesionalisme auditor terhadap pengungkapan fraud memiliki t hitung sebesar 0.996. Oleh karena t hitung $<\mathrm{t}$ tabel $(0,996<2,007)$, maka dapat disimpulkan bahwa $\mathrm{H} 3$ ditolak. Artinya tidak ada pengaruh profesionalisme auditor terhadap pengungkapan kecurangan. Kurangnya keteguhan hati auditor selama pelaksanaan audit dapat menyebabkan tidak berpengaruhnya profesionalisme auditor dalam mengungkapan kecurangan. Profesionalisme auditor tidak berpengaruh terhadap pengungkapan kecurangan karena walaupun auditor memiliki profesionalisme auditor yang baik dan sudah banyak melakukan penugasan bisa juga mengalami kegagalan dalam 
melakukan pengungkapan kecurangan. Kegagalan tersebut bisa disebabkan karena kesulitan dalam memperoleh data dan informasi yang dibutuhkan, tidak mengambil pertimbangan dalam membuat keputusan, kegagalan dalam mencari penyebab munculnya kesalahan, tidak profesional dalam memprediksi dan mendeteksi masalah, kurang teliti dan kurang cermat dalam melakukan pemeriksaan dan kurangnya belajar dari kegagalan dan keberhasilan yang pernah dialami.

Profesionalisme auditor merupakan hal yang penting bagi auditor untuk dapat melaksanakan tugasnya dengan baik. Namun, dalam penelitian ini profesionalisme auditor tidak berpengaruh terhadap pengungkapan kecurangan. Hasil penelitian ini sejalan dengan penelitian yang dilakukan Rahayu (2018).

\section{Hasil Uji Moderate Regresion Analysis}

Analisis Moderate Regression Analysis (MRA) digunakan untuk pengujian hipotesis 4, 5 dan 6. Hasil dan pembahsan untuk masing-masing hipotesis tersebut disajikan sebeagi berikut.

Kecerdasan Spritual Memoderasi Pengaruh Teknik Audit Investigatif Terhadap Pengungkapan Kecurangan

Hasil pengujian MRA untuk Hipotesis 4 (H4) disajikan pada tabel 4 berikut:

\section{Tabel 4}

Hasil Uji Analisis Regresi Moderasi H4

\begin{tabular}{|c|c|c|c|c|c|}
\hline \multicolumn{6}{|c|}{ Coefficients $^{\mathrm{a}}$} \\
\hline \multirow[b]{2}{*}{ Model } & \multicolumn{2}{|c|}{ Unstandardized Coefficients } & \multirow{2}{*}{$\begin{array}{c}\text { Standardized } \\
\text { Coefficients } \\
\text { Beta }\end{array}$} & \multirow[b]{2}{*}{$\mathrm{t}$} & \multirow[b]{2}{*}{ Sig. } \\
\hline & B & Std. Error & & & \\
\hline 1 (Constant) & 18.190 & 6.981 & & 2.606 & .012 \\
\hline Teknik Audit Investigatif & .550 & .185 & .455 & 2.974 & .004 \\
\hline Kecerdasan Spiritual & .054 & .092 & .082 & .587 & .560 \\
\hline $\begin{array}{l}\text { Teknik Audit } \\
\text { Investigatif*Kecerdasan Spiritual }\end{array}$ & .000 & .003 & -.026 & 1.876 & .046 \\
\hline a. Dependent Variable: Pengungkapa & Fraud & & & & \\
\hline
\end{tabular}

Sumber: Data Olahan SPSS, 2019

Berdasarkan Tabel 4 diatas, maka persamaan regresi moderasi yang didapatkan adalah sebagai berikut:

$$
Y=18.190+0.550 \times 1+0.054 Z+0.000 \times 1 Z
$$

Dari Tabel 4 dapat dilihat bahwa kecerdasan spiritual dapat memoderasi hubungan antara teknik audit investigatif (X1) terhadap pengungkapan fraud yang memiliki tingkat 
signifikansi 0.046 (kecil dari $\alpha=5 \%$ ). Artinya kecerdasan spiritual dapat memoderasi hubungan antara teknik audit investigatif terhadap pengungkapan kecurangan. Maka dapat disimpulkan bahwa $\mathrm{H} 4$ diterima.

Seorang auditor yang mempunyai kemampuan (skill) dan memahami teknik audit investigatif dalam suatu investigasi diharapkan mampu menentukan kebenaran suatu permasalahan melalui proses pengujian, pengumpulan dan pengevaluasian bukti-bukti yang relevan dengan perbuatan kecurangan yang nantinya akan diungkap. Kecerdasan spiritual yang dimiliki seorang auditor dalam proses investigatif dapat memutuskan mana yang baik dan tidak baik, sehingga dalam pelaksanaan investigatif auditor dapat menentukan kebenaran permasalahan melalui proses pengujian, pengumpulan dan pengevaluasian bukti-bukti yang relevan dengan perbuatan kecurangan dan juga dapat mengungkapkan fakta-fakta kecurangan sehingga dapat mengidentifikasi pelaku kecurangan.

Hasil penelitian ini sejalan dengan penelitian Nurmin (2017) yang menyatakan bahwa kecerdasan spritual dapat memperkuat hubungan teknik audit investigatif terhadap pengungkapan kecurangan.

\section{Kecerdasan Spritual Memoderasi Pengaruh Pengalaman Auditor Terhadap Pengungkapan Kecurangan}

Hasil pengujian MRA untuk Hipotesis 5 (H5) disajikan pada tabel 5 berikut:

\section{Tabel 5}

\section{Hasil Uji Analisis Regresi Moderasi H5}

\begin{tabular}{|c|c|c|c|c|c|}
\hline \multicolumn{6}{|c|}{ Coefficients $^{\mathbf{a}}$} \\
\hline \multirow[b]{3}{*}{ Model } & \multirow{2}{*}{\multicolumn{2}{|c|}{ Unstandardized Coefficients }} & \multirow{3}{*}{$\begin{array}{c}\text { Standardized } \\
\text { Coefficients }\end{array}$} & \multirow[b]{3}{*}{$\mathrm{t}$} & \multirow[b]{3}{*}{ Sig. } \\
\hline & & & & & \\
\hline & $\mathrm{B}$ & Std. Error & & & \\
\hline 1 (Constant) & 90.295 & 26.424 & & 3.417 & .001 \\
\hline Pengalaman Auditor & -1.587 & .784 & -1.227 & -2.024 & .048 \\
\hline Kecerdasan Spiritual & -.899 & .472 & -1.128 & -1.905 & .062 \\
\hline $\begin{array}{l}\text { Pengalaman Auditor*Kecerdasan } \\
\text { Spiritual }\end{array}$ & .027 & .012 & 1.808 & 2.179 & .034 \\
\hline
\end{tabular}

Sumber: Data Olahan SPSS, 2019

Berdasarkan Tabel 5 diatas, maka persamaan regresi moderasi yang didapatkan adalah sebagai berikut:

$$
Y=90.295-1.587 \mathrm{X} 2-0.899 \mathrm{Z}+0.027 \mathrm{X} 2 \mathrm{Z}
$$

Dari Tabel 5 dapat dilihat bahwa kecerdasan spiritual dapat memoderasi hubungan pengalaman auditor (X2) terhadap pengungkapan fraud yang memiliki tingkat signifikansi 
0.034 (kecil dari $\alpha=5 \%$ ). Artinya kecerdasan spiritual dapat memoderasi pengaruh pengalaman auditor terhadap pengungkapan kecurangan. Maka dapat disimpulkan bahwa H5 diterima.

Dapat dilihat dari Tabel 5, hasil analisis regresi moderating menunjukkan bahwa interaksi kecerdasan spritual dan pengalaman auditor terhadap pengungkapan fraud merupakan variabel moderasi dengan hasil signifikan. Hal ini berarti bahwa hipotesis keempat mengatakan bahwa kecerdasan spritual memoderasi pengalaman auditor terhadap pengungkapan fraud terbukti.

Maka dapat disimpulkan, seorang auditor yang sudah mempunyai pengalaman kerja yang lama tidak berkemungkinan untuk bisa mengungkapkan kecurangan tetapi jika seorang auditor tersebut memiliki kecerdasan spiritual, maka auditor tersebut mampu mengungkapkan kecurangan. Auditor yang sudah berpengalaman namun jarang menemukan kasus laporan keuangan yang curang akan sulit untuk menemukan kecurangan. Dengan adanya kecerdasan spiritual yang dimiliki oleh seorang Auditor akan membantu Auditor untuk menemukan dan mengungkapkan kecurangan yang terjadi. Kecerdasan spiritual auditor akan membantu auditor untuk lebih aktif dalam menyelesaikan masalah yang dihadapinya.

Hasil penelitian ini sesuai dengan penelitian sebelumnya yang dilakukan Hasbi (2019) yang menemukan kecerdasan spiritual memoderasi pengaruh pengalaman auditor terhadap pengungkapan kecurangan.

\section{Kecerdasan Spritual Memoderasi Pengaruh Profesionalisme Auditor Terhadap Pengungkapan Fraud}

Hasil MRA hipotesis 6 dapat dilihat pada tabel 6 berikut :

\section{Tabel 6}

\section{Hasil Uji Analisis Regresi Moderasi H6}

\begin{tabular}{|c|c|c|c|c|c|c|}
\hline \multirow{2}{*}{\multicolumn{2}{|c|}{ Model }} & \multicolumn{2}{|c|}{ Unstandardized Coefficients } & \multirow{2}{*}{$\begin{array}{c}\begin{array}{l}\text { Standardized } \\
\text { Coefficients }\end{array} \\
\text { Beta } \\
\end{array}$} & \multirow[b]{2}{*}{$\mathrm{t}$} & \multirow[b]{2}{*}{ Sig. } \\
\hline & & $\mathrm{B}$ & Std. Error & & & \\
\hline \multirow[t]{4}{*}{1} & (Constant) & 41.308 & 12.571 & & 3.286 & .002 \\
\hline & Profesionalisme Auditor & .384 & .103 & .487 & 3.725 & .000 \\
\hline & Kecerdasan Spiritual & .074 & .087 & .112 & .854 & .397 \\
\hline & $\begin{array}{l}\text { Profesionalisme } \\
\text { Auditor*Kecerdasan Spiritual }\end{array}$ & -.413 & .275 & -.204 & 1.365 & .014 \\
\hline \multicolumn{7}{|c|}{ a. Dependent Variable: PengungkapanFraud } \\
\hline
\end{tabular}

Berdasarkan Table 6 diatas, maka persamaan regresi moderasi yang didapatkan adalah sebagai berikut:

$$
Y=41.308+0.384 \times 3+0.074 Z-0.413 \times 3 Z
$$


Dari Tabel 6 dapat dilihat bahwa kecerdasan spiritual dapat memoderasi hubungan profesionalisme auditor (X3) terhadap pengungkapan kecurangan yang memiliki tingkat signifikansi 0.014 (kecil dari $\alpha=5 \%$ ). Artinya kecerdasan spiritual dapat memoderasi hubungan antara profesionalisme auditor terhadap pengungkapan kecurangan. Maka dapat disimpulkan bahwa H6 diterima.

Meskipun seorang auditor profesional dalam melaksanakan tugasnya tetapi tidak memiliki pengetahuan tentang kecerdasan spritual tetap saja auditor mungkin akan melakukan tindak kecurangan. Maka dari itu, kecerdasan spiritual memungkinkan manusia untuk berpikir kritis, berwawasan jauh, membuat atau bahkan mengubah aturan, yang membuat orang tersebut dapat berkerja lebih baik. Sesuai dengan teori atribusi menunjukkan bahwa perilaku seseorang ditentukan oleh kombinasi antara kekuatan internal (internal forces), yaitu faktorfaktor yang berasal dari dalam diri seseorang, seperti kemampuan atau usaha, dan kekuatan eksternal (eksternal forces), yaitu faktor-faktor yang berasal dari luar seperti kesulitan dalam pekerjaan atau keberuntungan. Orang yang memiliki kecerdasan spiritual tinggi mampu memaknai hidup dengan memberi makna positif pada setiap persitiwa, masalah, bahkan penderitaan yang dialaminya. Dengan memberi makna yang positif akan mampu membangkitkan jiwa dan melakukan perbuatan dan tindakan yang positif.

Tanpa adanya kecerdasan spiritual sangat sulit untuk auditor menyelesaikan konflik yang menjadi bagian atau risiko profesi dan memikul tanggung jawab seperti apa yang disebutkan dalam pedoman kode etik akuntan Indonesia serta tidak menyalahgunakan kemampuan dan keahlian merupakah amanah yang dimilikinya kepada jalan yang tidak dibenarkan. Hasil tersebut dapat berpengaruh terhadap hasil kinerja mereka (Lisda, 2009).

\section{SIMPULAN}

Dari hasil penelitian ini dapat disimpulkan bahwa teknik audit investigatif berpengaruh terhadap pengungkapan kecurangan (studi pada BPKP Perwakilan Provinsi Riau). Sedangkan pengalaman auditor dan proefsionalisme auditor tidak berpengaruh terhadap pengungkapan kecurangan. Dari hasil penelitian ini, kecerdasan spiritual dapat memoderasi teknik audit investigatif, pengalaman auditor dan profesionalisme auditor terhadap pengungkapan kecurangan.

Saran untuk peneliatian selanjutnya: 1) Sebaiknya memperluas objek penelitian pada audit internal pemerintah seperti di BPKP, KAP dan Inspektorat yang tidak terbatas pada auditor di Kantor BPKP RI Perwakilan Riau (audit eksternal). 2) Bagi BPKP RI penelitian ini dapat dijadikan pertimbangan dalam melakukan penunjukan terhadap auditor yang akan 
melakukan pemeriksaan apakah auditor tersebut memiliki konflik kepentingan dalam hal hubungan persaudaraan atau konflik kepentingan lainnya yang dapat mempengaruhi pengungkapan fraud tersebut. Hasil penelitian ini sejalan dengan penelitian Dharmawan (2013).

\section{REFERENSI}

Asad, M.T (2016) Pengaruh Profesionalisme Dan Pengalaman Auditor Forensik Terhadap Kompetensi Bukti Audit Dalam Pengungkapan Kecurangan Tindak Pidana Korupsi,Skripsi, Universitas Negeri Jakarta

Dharmawan, S. N. A . (2013). Pengaruh Kecerdasan Intelektual, Kecerdasan Emosional dan Kecerdasan Spiritual Terhadap Profesionalisme Kerja Auditor. Jurnal Undiksha.

Fauzan, A, I., Purnamasari, P., \& Gunawan, H. (2015). Pengaruh Akuntansi Forensik dan Audit Investigasi terhadap Pengungkapan Fraud. Prosiding Akuntansi. 456-465.

Hasbi, A. S. W. (2019). Pengaruh Audit Forensik, Audit Investigatif, Professional Gudgement Terhadap terhadap Pengungkapan Fraud dengan Kecerdasan Spiritual Sebagai Variabel Moderating. Skripsi. Fakultas Ekonomi dan Bisnis Islam, UIN Alaudin Makasar.

Lisda, A. (2009). Pengaruh Kecerdasan Intelektual, Kecerdasan Emosional dan Kecerdasan Spiritual Terhadap Perilaku Etis Auditor Serta Dampaknya Terhadap Kinerja. Skripsi. Jakarta.

Novianti \& Bandi. (2011). Pengaruh Pengalaman dan Pelatihan Terhadap Struktur Pengetahuan Auditor tentang Kekeliruan. Skripsi. Universitas Negeri Semarang

Nurmin. (2017). Pengaruh Profesionalisme Auditor Terhadap Pengungkapan Kecurangan. Jurnal Akuntansi. 14-26.

Ramadhaniyati, Y. \& Hayati, N. (2014). Pengaruh Profesionalisme, Motivasi, Integritas, dan Independensi Satuan Pengawasan Internal dalam Mencegah Kecurangan (Fraud) di Lingkungan Perguruan Tinggi Negeri. JAFFA. 2 (2). 101-114.

Rozali,R.D.Y \& Darliana ,C.F (2015) Teknik Audit Investigatif Dalam Pengungkapan Money Laundering Berdasarkan Perspektif Akuntan Forensik, Jurnal Riset Akuntansi dan Keuangan (JRAK)

Setiawati, M.P dan Sari,M.M.R., (2016) Profesionalisme, Komitmen Organisasi, Intensitas Moral Dan Tindakan Akuntan Melakukan Whistleblowing. E Jurnal Akuntansi

Sundari, T. E. (2018). Pengaruh Teknik-Teknik Audit Investigatif Terhadap Pendeteksian Kecurangan dan Profesionalisme Auditor Forensik Di Indonesia. Seminar Nasional Hasil Penelitian dan Pengabdian Masyarakat. 1 (1). 
Surtiyana, G. R. (2014). Pengaruh Keahlian Audit dan Pengalaman Audit Terhadap Kemampuan Auditor Mendeteksi Kecurangan. Skripsi. Universitas Widyatama Bandung.

Wahono, S. (2011). Artikel Audit Investigasi.

Zohar, D. \& Marshal, I. (2007). SQ: Kecerdasan Spiritual. Bandung: Mizan. 